\title{
Evaluation of Pansy Cultivars as Bedding Plants to Select the Best-of-class
}

\author{
Richard O. Kelly ${ }^{1}$, Rick K. Schoellhorn ${ }^{2}$, Zhanao Deng ${ }^{1}$, and \\ Brent K. Harbaugh ${ }^{1}$
}

AdDitional InDEX wORds. Pansy, Viola $\times$ wittrockiana, variety trial, bedding plants

SumMARY. Florida is one of the top wholesale producers of bedding plants, and in 2003 was ranked fourth in annual bedding plant production and fifth in potted pansy/viola production. Evaluation of pansy cultivars is vital for continued growth of the industry. We evaluated 210 cultivars of pansy (Viola $\times$ wittrockiana) (164 new cultivars) in replicated class tests at the University of Florida's Gulf Coast Research and Education Center at Bradenton, Fla., from 2000-04 to determine the best-of-class and use them in future trials to compare against new entries in the same class. In this report, we provide objective plant measurements of vegetative and floral characteristics as well as subjective performance ratings. Subjective ratings were on a 1 to 7 scale with the highest rating of 7 for excellent. In general, overall performance ratings (combined foliage, flower, arthropod, and disease ratings) $\geq 5.5$ were considered outstanding. Pansy cultivars were grouped into classes based on flower color and pattern. Best-of-class selections that had an outstanding overall performance rating in one or more contested trials, never falling below 5.0 in other contested trials, were: (black class) 'Accord/ Banner Black Beauty', (blue shades/tints class) 'Nature Blue', (blue with blotch class) 'Nature Ocean', (mix class) 'Panola Clear Mixture', (pink shades/tints with blotch class) 'Nature Pink Shades', [purple (dark), blue-violet with white cap class] 'Nature Beacon', [purple (dark), blue-violet/white face with blotch class] 'Panola Purple With Face', (purple with light eye class) 'Baby Bingo Lavender Blue', (white class) 'Nature White', (yellow class) 'Nature Yellow', (yellow with blotch and purple, blue-violet cap class) 'Iona Purple \& Yellow With Blotch', (yellow with blotch and red cap class) 'Bingo Red \& Yellow', (yellow with blotch and red cap class ) 'Panola Yellow With Blotch', (yellow with dark veins class) 'Whiskers Yellow'. We believe these cultivars would perform well in the southern U.S. or areas of the world with similar heat and cold hardiness zones.

$\mathrm{O}$ ne of the oldest garden flowers is the pansy (from the French word pensee, meaning thought; folk-name: heartsease). John Parkinson mentions its use in 1629. Records indicate their use in medicine by the Greeks in the 4th century BCE. Hybrid pansies were created from violas, a large genus of 500 species. During this same period, it is believed that a European observed a plant similar to viola found in open, sunlit areas and called it a wild pansy. William Thompson, an English gardener in the early 19th century, made

${ }^{1}$ University of Florida, IFAS, Environmental Horticulture Department, Gulf Coast Research and Education Center, 14625 CR 672, Wimauma, FL 33598.

${ }^{2}$ University of Florida, IFAS, Environmental Horticulture Department, Gainesville, FL 32611

This research was supported by the Florida Agricultural Experiment Station, and approved for publication as Journal Series R-10669. We thank Joyce Jones, Nancy West, Gail Bowman, Paulette Blanton, and Jenna Adams for their excellent technical support. crosses with Viola tricolor, V. lutea, and a blue flowered species thought to be of Russian origin. Thompson is credited with discovering the cross that began the new interspecific hybrid species V.×wittrockiana (Bailey, 1947; Texas A\&M, 1997; U.S. Department of Agriculture, 2004a).

In the USDA 1998 Census of HorticulturalSpecialties(U.S. Department of Agriculture, 1998), pansy/viola ranked third for wholesale value of flats (\$57 million) and fourth for pots (\$19 million). Of the bedding plants surveyed with highest sales value to growers in 2003, pansy/viola flats contributed the second largest amount at $\$ 118$ million behind potted gerani-

\begin{tabular}{llll}
\hline $\begin{array}{l}\text { Units } \\
\text { To convert } \\
\text { U.S. to SI, } \\
\text { multiply by }\end{array}$ & U.S. unit & SI unit & $\begin{array}{l}\text { To convert } \\
\text { SI to U.S., } \\
\text { multiply by }\end{array}$ \\
\hline 0.3048 & $\mathrm{ft}$ & $\mathrm{m}$ & 3.2808 \\
0.0929 & $\mathrm{ft}^{2}$ & $\mathrm{~m}^{2}$ & 10.7639 \\
2.5400 & inch $(\mathrm{es})$ & $\mathrm{cm}$ & 0.3937 \\
1.1209 & $\mathrm{lb} / \mathrm{acre}$ & $\mathrm{kg} \cdot \mathrm{ha}^{-1}$ & 0.8922 \\
28.3495 & $\mathrm{Oz}$ & $\mathrm{g}$ & 0.0353 \\
$\left({ }^{\circ} \mathrm{F}-32\right) \div 1.8$ & ${ }^{\circ} \mathrm{F}$ & ${ }^{\circ} \mathrm{C}$ & $\left(1.8 \times{ }^{\circ} \mathrm{C}\right)+32$
\end{tabular}


ums (from cuttings and seed) at $\$ 150$ million. Florida was fifth in the U.S. for the number of potted pansies/violas produced, and their wholesale value was $\$ 2.0$ million in 2003 (U.S. Department of Agriculture, 2004b).

The bedding plant industry requires timely evaluation of cultivars for a competitive market. Many of the bedding plant cultivar trials currently conducted in the U.S. are performed without replicated experimental units. While those trials provide valuable observational information, they require replication over years to gain the benefits from statistical analysis. Since seed companies are releasing new cultivars yearly, timely evaluations are critical to provide growers with nonbiased performance evaluations to help them make cultivar selection decisions. Standards have not been developed for pansies and thus new cultivars are often compared with a random number of cultivars chosen from over $300 \mathrm{com}$ mercially available cultivars (Kessler, 1998). This study was done to evaluate pansy cultivar performance in seasonal replicated trials to provide evaluations that may be used by growers, landscapers, consumers and seed companies as well as the scientific community. These trials also were to establish cultivars to be used as standards (best-of-class) for comparing new cultivars as they become available without the need to re-evaluate all older cultivars.

\section{Materials and methods}

Four trials were conducted between Dec. 2000 and Mar. 2004. The initial trial was concluded in 2001, evaluating 87 cultivars, and was used to establish best-of-class standards to be used as comparisons for new cultivar releases in future trials. Cultivars were placed into classes based on flower color and pattern (Table 1). In 2001, some new classes were created as we felt some colors/patterns were so distinctly different as to warrant further separation. In all four trials, some cultivars were the sole entry for that class and were evaluated as uncontested. Forty-three new cultivars were evaluated in 2002 , 22 in 2003, and 12 in 2004.

Seeds were sown on 4-5 Dec. 2000, 4-10 Oct. 2001, 10-17 Oct. 2002 and 6-20 Oct. 2003. Immediately after germination, seedlings were transplanted into Todd planter flats (model 128; Speedling Inc., Sun City, Fla.) with cells $1.5 \times 1.5 \times 2.5$ inches, and grown to mature non-flowering plugs in a greenhouse. One to two weeks before transplanting into the field, flats were placed outside in full sun for hardening. Plugs were transplanted on 31 Jan. 2000-1 Feb. 2001, 27-29 Nov. 2001, 11 Dec. 2002, and 17-24 Nov. 2003 into raised ground beds 32 inches wide $\times 8$ inches high of EauGallie fine sand $(\mathrm{pH}$ range $=$ 6.2-6.8). Six plants per plot spaced 9 inches apart and arranged from the bed center in two three-plant rows across the bed width for a $2 \mathrm{ft}^{2}$ plot with an equal area between plots.

Solid fertilizer was applied by hand to each plant on the soil surface approximately 1 inch from the plant stem under the plastic mulch in 2000-01 and 2001-02 at $0.5 \mathrm{oz}$ per plant, using Nutricote 13-13-13 fertilizer $(13 \mathrm{~N}-5.7 \mathrm{P}-10.8 \mathrm{~K}, 100 \mathrm{~d}$ slow-release type; Florikan, Sarasota, Fla.); Osmocote Plus 15-9-12 fertilizer $(15 \mathrm{~N}-3.9 \mathrm{P}-10 \mathrm{~K}, 5-6$ months slow-release type with micronutrients; Scotts Co., Maryville, Ohio) was used at the same rate in 2002-03 and 2003-04. Beds were fumigated $\geq 14 \mathrm{~d}$ before planting with a mixture of $66 \%$ methyl bromide and 33\% chloropicrin at $350 \mathrm{lb} /$ acre and covered with whiteon-black polyethylene film. Subsurface seepage irrigation water was supplied from lateral ditches spaced $40.5 \mathrm{ft}$ apart (Howe and Waters, 1989).

Integrated pest management was employed to determine when pesticide applications were needed to control arthropod pests and plant pathogens. Weather information was recorded by a University of Florida automated weather station [University of Florida, Gulf Coast Research and Education Center, Bradenton; lat. $27^{\circ} 4^{\prime} \mathrm{N}$, long. $82^{\circ} 5^{\prime} \mathrm{W}$; AHS Heat Zone 10 (American Horticultural Society, 1999); USDA Cold Hardiness Zone 9b (U.S. National Arboretum, 1990)].

Between 14-15 Mar. 2001, on 15 Feb. 2002, between 5-6 Feb. 2003, and on 26 Jan. 2004, plant height (from the stem base to the inflorescence tip), plant width at the widest point and flower diameter were recorded for three plants selected from the center and edge of each plot. Subjective ratings were made by the senior author between 28 Feb. and 10 Apr. 2001, 16 Jan. and 2 Mar. 2002, 15 Jan. to 29 Mar. 2003 and 7 Jan. to 5 Mar. 2004 (evaluations were across all six plants resulting in one value per plot). A scale of 1 to 7 scale was used with the highest rating a 7 . Floral characteristics were rated within a scale as follows: 7 = flowers were numerous, uniformly distributed over all plants, flowers were free from pest symptoms; $4=$ average floral display, may have some pest damage but not severe enough to cause flowers to be unacceptable; and $\mathrm{l}=$ unacceptable flower number or display, and/or pest damage severe resulting in unattractive flowers. Foliage ratings were as follows: 7 = all plants in a plot had full and uniform foliage, plants were free of pest symptoms and abnormalities or weaknesses such as lodging; 4 = average foliage density, minimal lodging, and/or some insect damage but foliage was still acceptable; 1 = foliage sparse, stem lodging, and/or unacceptable pest damage making plants undesirable. Arthropod and disease ratings on flowers were as follows: 7 = all flowers free from arthropod feeding scars and absence of diseased tissue in the form of spots, blights, or tissue distortion caused by a pathogen; $4=$ minimal pest damage to tissue, and flowers still acceptable; 1 = flowers severely infested and damaged, resulting in undesirable flowers. For a measure of performance over time, ratings were added and divided by the total number of ratings ( two to four per trial). For a measure of overall performance, flower, foliage, arthropod, and disease ratings were added and divided by four. For each class, the cultivar with the highest overall performance rating was selected as best-of-class. If the rating was a tie, another rating was chosen. These cultivars were then used in trials 2-4 as the "standard" for comparison of new cultivars in their class. Some cultivars were the sole entry in their class, so they became uncontested best-of-class.

Each class was analyzed as a separate experiment. A randomized complete-block experimental design was used with three or four blocks containing six plants per plot. The experimental unit for objective data was the average measurement from three plants, and for subjective data, one rating value considering all six plants in the plot. All data were analyzed by analysis of variance (ANOVA) methods, and means of dependent variables significant at the 0.05 level of probability were separated using Duncan's multiple range test (PROC ANOVA; SAS Institute, Cary, N.C.). 
Table 1. Plant and flowering characteristics and performance ratings for pansies grown in winter/spring 2000-01 in Bradenton, Fla., grouped within classes according to flower color. Seeds were sown on 4-5 Dec. 2000, and plugs transplanted to ground beds 31 Jan. 2000-1 Feb. 2001.

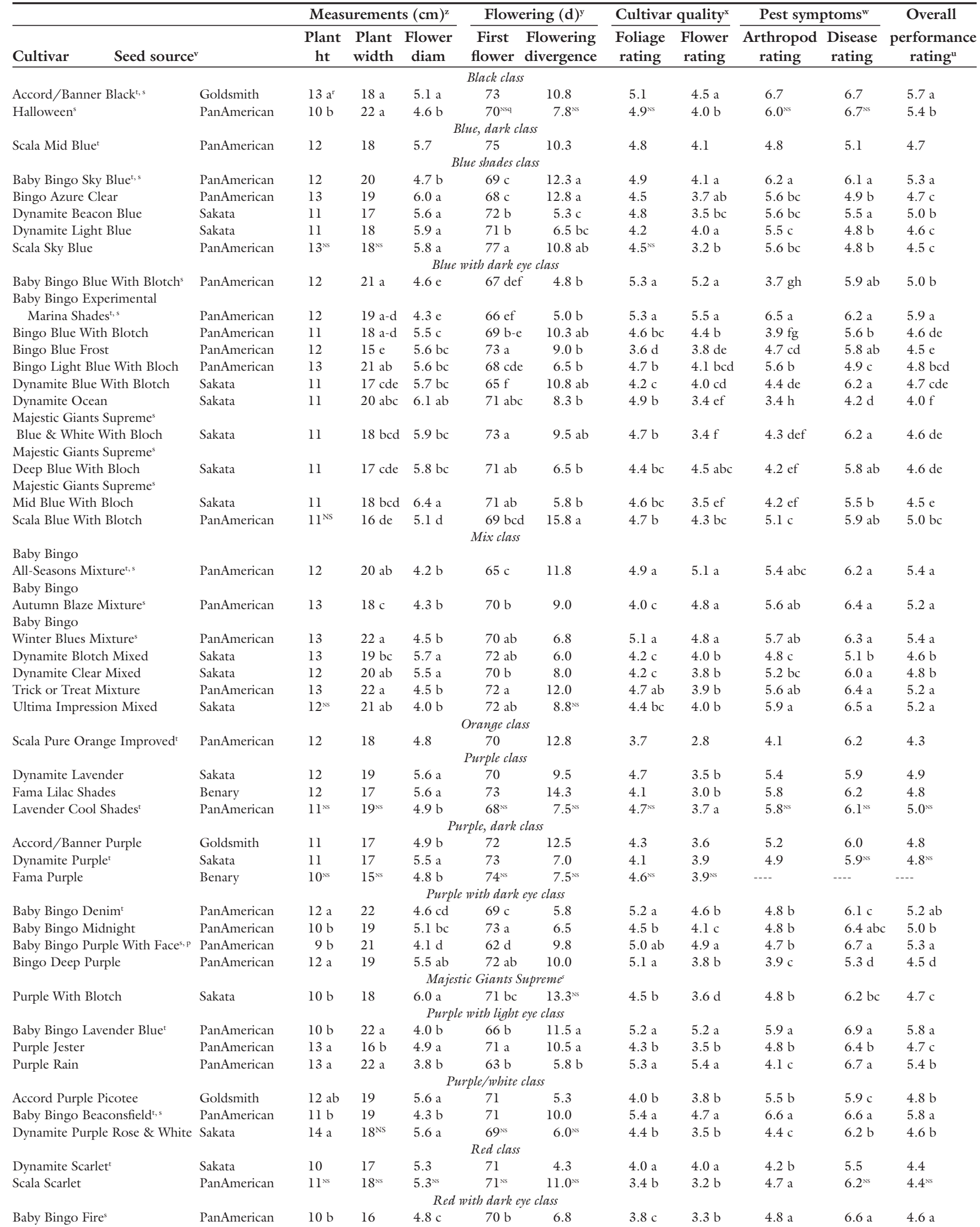

Table 1. Continued on next page. 
Table 1. Continued from previous page.

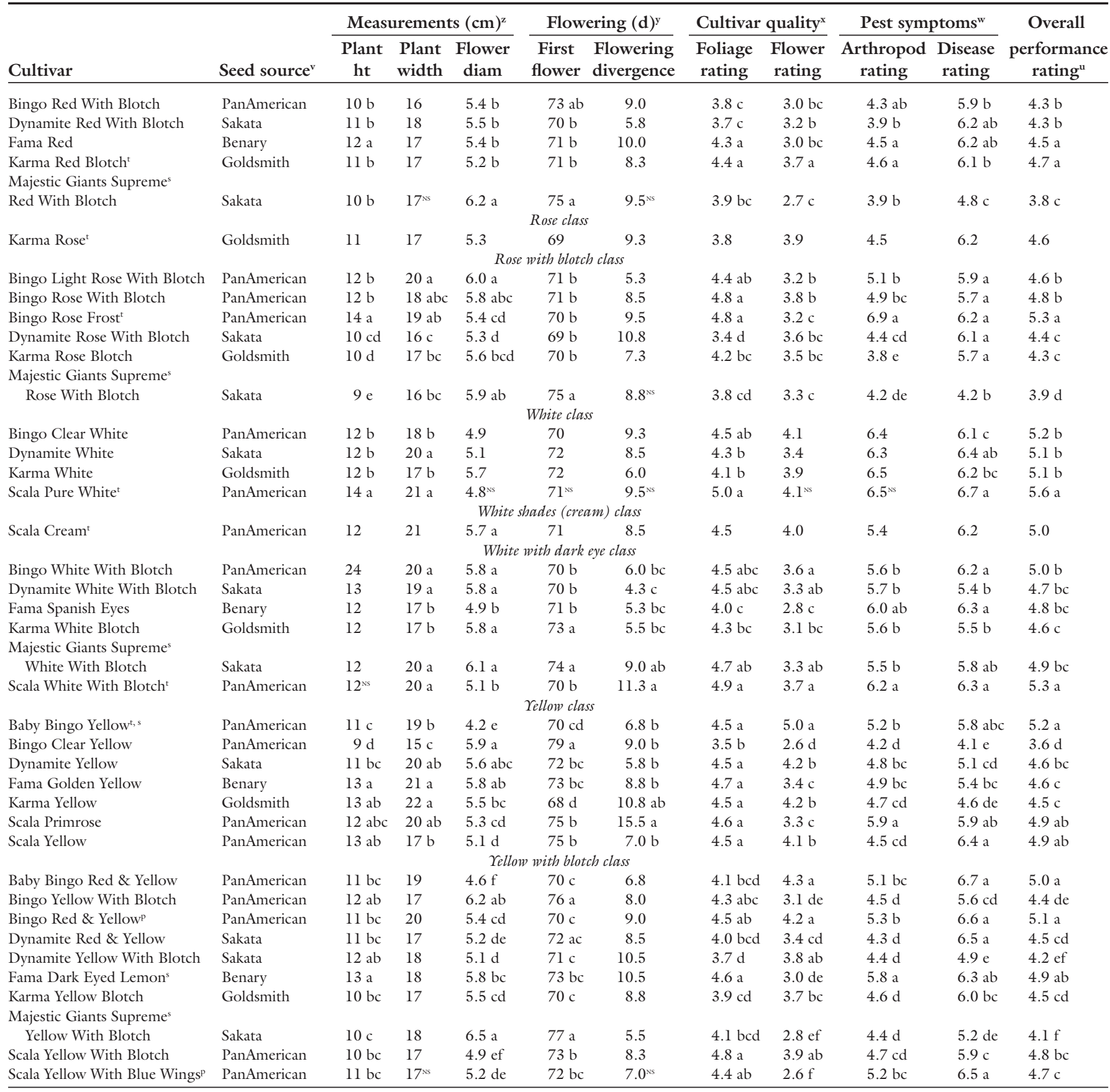

${ }^{z} 1 \mathrm{~cm}=0.3937$ inch.

yThe number of days from sowing seed to the unfurling of the first flower in a plot. Divergence is the average number of days that lapse between the unfurling of the first flower and the last flower in a plot, or a measure of uniform flowering.

xAverage of four foliage or flower quality ratings taken between $28 \mathrm{Feb}$. and 27 Mar. on a scale of 1 to 7 with 7 = excellent.

"Average of three arthropod or disease ratings for flowers taken between 9 Mar. and 10 Apr. on a scale of 1 to 7 with $7=$ all flowers in a plot were free from arthropod feeding or plant disease symptoms; no foliage pests observed.

'Seed Sources: Benary = Ernst Benary of America, Sycamore, Ill.; Goldsmith = Goldsmith Seeds, Gilroy, Calif.; PanAmerican = PanAmerican Seed Co., West Chicago, Ill.; Sakata $=$ Sakata Seed America, Morgan Hill, Calif.

"Overall performance rating is the average of the foliage, flower, arthropod and disease ratings.

'Best-of-class chosen from the overall performance rating or by another rating, if overall performance values were equal.

'Cultivar names were later changed by the seed company: 'Panola' series was created from 'Baby Bingo' and 'Panache' (see Table 2); 'Baby Bingo Yellow' became 'Panola Golden Yellow'; those 'Baby Bingo' best-of-class replaced by different genetics are considered improvements to be used for future comparisons. 'Halloween II' replaced 'Halloween'. 'Accord/Banner Black' became 'Accord/Banner Black Beauty'; 'Scala Pure Orange' became 'Scala Orange' (see Table 2); 'Majestic Giants Supreme' became 'Majestic Giants II' (see Table 3).

${ }^{r}$ Mean separation within classes by Duncan's multiple range test, $P<0.05$

PIndicates class was divided and a cultivar became a new class (thus, an uncontested best-of-class) or a class name was revised. Class changes were: 'Baby Bingo Purple With Face' [('Panola Purple With Face') purple (dark), blue-violet/white face with blotch; Tables 2-4]; 'Bingo Red \& Yellow' (yellow with blotch and red cap; uncontested); and 'Scala Yellow With Blue Wings' (yellow with blotch and purple, blue-violet cap; Table 3).

${ }^{\mathrm{s} N}$ Nonsignificant. 


\section{Results and discussion}

Average monthly temperatures during the four trials ranged from 12.1 ${ }^{\circ} \mathrm{C}$ in Jan. 2003 to $22.1^{\circ} \mathrm{C}$ in Mar. 2003 and ranges from the lowest to the highest temperature of $-2.49^{\circ} \mathrm{C}$ in Jan. 2003 to $31.7^{\circ} \mathrm{C}$ in Mar. 2002. Total rainfall ranged from 0.0 inches in Nov., Feb. and Apr. 2001 to 10.8 inches in Mar. 2001 (Florida Automated Weather Network, 2004).

Three main pests lowered ratings. Thrips (Frankliniella spp.) and graymold (Botrytis cinerea) symptoms were observed on flowers every season, while powdery mildew (unidentified) was first observed on foliage (flowers symptom-free) in these trials in Mar. 2003-04. The mildew species Sphaerotheca macularis, S. fuliginea, and $S$. violae have been isolated from Viola spp. in the U. S. (Farr, 1989), while only $S$. macularis had been reported earlier in Florida (Florida Department of Agriculture and Consumer Services, 1994).

Best-of-class selections are presented below for each class, with the trial year when the cultivar was first established as best-of-class and in additional trials when compared to new cultivars. The trial year corresponds to its table as follows: 2001 (Table 1), 2002 (Table 2), 2003 (Table 3) and 2004 (Table 4). We realize a particular plant height, flower size, or flowering characteristic such as earliness to flower may be a selection criteria outweighing seasonal performance, so these characteristics are presented in Tables 1 to 4 . It is also important to note that cultivars can be selected as bestof-class and have poor to outstanding performance ratings. Cultivars with an overall rating $>5.5$ were considered outstanding, $5.0-5.4$ as good, $4.0-4.9$ as fair, and $<4.0$ as poor.

Black Class. 'Accord/Banner Black' was best-of-class in 2001 ('Accord/Banner Black Beauty' after trial) with an overall performance rating of 5.7 compared to 5.4 for 'Halloween'.

Blue shades/tints class. 'Nature Blue' was established as bestof-class in 2002 (class name changed from shades to shades/tints in 2003) with an overall performance rating of 5.8. Other cultivars ranged from 4.3 for 'Atlas Blue' and 'Atlas Blue Splash' to 4.9 for 'Springtime Mid-Blue'. In 2003, 'Nature Blue' had a rating of
6.3 compared to 5.1 for 'Fama Silver Blue', and in 2004, it had a rating of 6.2 compared to 5.5 for 'Atlas Sky Blue', and thus remained best of class.

BLUE WITH BLOTCH CLASS. 'Nature Ocean' was established as best-of-class in 2002 with an overall performance rating of 5.5. Other cultivars ranged from 4.1 for 'Colossus Deep Blue With Blotch' and 'Iona Ocean' to 5.4 for 'Baby Bingo Experimental Marina Shades' (renamed 'Panola Marina Shades', best-of-class in the 2001 trial; class name changed from dark eye to blotch in 2002). In 2004, 'Nature Ocean' had a rating of 5.9 compared to 5.3 for 'Karma Blue Blotch Improved', and thus remained best of class.

Blue (DARK) ClASS. 'Scala Mid Blue' was best-of-class in 2001 with an overall performance rating of 4.7. Poor flower quality ratings all season and flower disease symptom ratings on 10 Apr. had the greatest impact on lowering performance for 'Scala Mid Blue'.

BLUE (DARK) WITH BLOTCH CLASS. 'Dynamite Deep Blue With Blotch' was best-of-class in 2003 with an overall performance rating of 4.8. Poor flower quality ratings all season resulted in the fairly low overall performance rating.

Cream class. 'Scala Cream' was best-of-class in 2001 with an overall performance rating of 5.0 (class name changed from white shades (cream) to cream in 2002).

Mrx Class. 'Panola Clear Mixture' was established as best-of-class in 2004 with an overall performance rating of 5.8 that was equal to that of 'Panola All-Seasons Mix', the former best-ofclass. In this case, 'Panola Clear Mixture' was selected best-of-class since it had a higher foliage and flower rating (5.5), compared to 5.1 for 'Panola AllSeasons Mix'. The overall performance rating for 'Dynamite Silhouette Mix' was 5.7 .

Orange Class. 'Panola Orange' was established as best-of-class in 2002 with an overall performance rating of 4.7, equal to the ratings for 'Fama Deep Orange' and the former best-of-class, 'Scala Pure Orange Improved' ('Scala Orange' after 2001 trial). In this case, 'Panola Orange' was selected using the average flower rating which was 3.1 compared to 2.2 and 3.0 ratings for 'Fama Deep Orange' and 'Scala Orange Improved', respectively. The overall performance rating ranged from 4.1 for 'Delta Premium Pure Deep
Orange' to 4.2 for 'Atlas Orange'. In 2003, 'Panola Orange' had a rating of 5.5 compared to 5.0 for 'Giga Orange' and 'Karma Clear Orange' ('Karma Orange' after trial).

Pink Shades/TinTs With BLOTCH CLAss. 'Nature Pink Shades' was established as best-of-class in 2002 with an overall performance rating of 5.6 compared to 4.8 for 'Springtime Pink Shades' (class name changed from pink to pink shades/tints in 2003).

Purple blue-violet with вLотсH. 'Baby Bingo Denim' (class name changed from dark eye to blotch in 2002) was established as best-of-class in 2001 with an overall performance rating of 5.2 compared to a range of 4.5 for 'Bingo Deep Purple' to 5.3 for 'Baby Bingo Purple with Face'. Since 'Baby Bingo Purple with Face' was placed into a new class (renamed 'Panola Purple with Face'), it was not considered for best-of-class.

Purple (DARK) Blue-violet Class. 'Bingo Clear Purple' was established as best-of-class in 2004 with an overall performance rating of 5.3 compared to 4.8 for 'Delta Pure Violet'. 'Delta Pure Violet' was bestof-class in 2002.

Purple (Dark), blue-violet WITH BLOTCH Class. 'Giga Blue With Blotch' was best-of-class in 2003 with an overall performance rating of 5.1.

Purple (DARK), Blue-violet / WHITE FACE WITH BLOTCH CLASS. 'Baby Bingo Purple With Face’ was removed from the purple with dark eye class after 2001 and renamed 'Panola Purple With Face'. It was established in this new class as best-of-class in 2002 with an overall performance rating of 5.3 compared to 4.9 for 'Fama See Me'. In 2003 , it had a rating of 5.8 compared to 5.4 for 'Iona Purple \& White', and thus remained best-of-class.

Purple (Dark), Blue-violet / WHITE FACE AND DARK VEINS CLASS. 'Whiskers Purple White' was established as best-of-class in 2003 with an overall performance rating of 5.4 .

Purple (DARK), Blue-violet WITH WHITE CAP CLASS. 'Nature Beacon' was established as best-of-class in 2002 with an overall performance rating of 5.7. Other cultivars ranged from 4.6 for 'Bingo Beaconsfield' to 5.3 for 'Panola Beaconsfield' and 'Springtime Beaconsfield'. 'Panola Beaconsfield' (formally named 'Baby Bingo Beaconsfield') was selected bestof-class in 2001. 
Table 2. Plant and flowering characteristics and performance ratings for pansies grown in winter/spring 2001-02 in Bradenton, Fla., grouped within classes according to flower color. Seeds were sown on 4-10 Oct. 2001, and plugs transplanted to ground beds on 27-29 Nov. 2001.

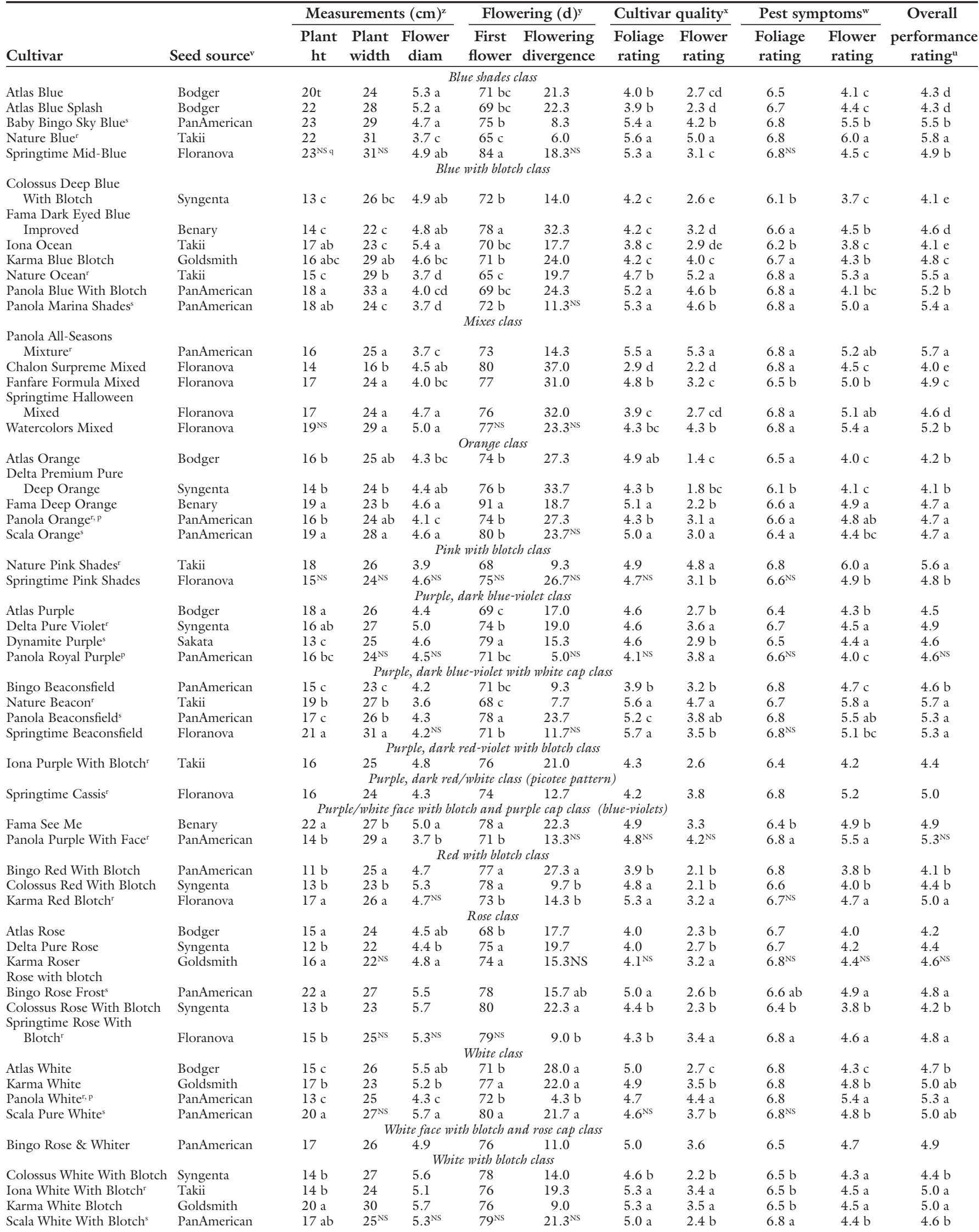

Table 2. Continued on next page. 
Table 2. Continued from previous page.

\begin{tabular}{|c|c|c|c|c|c|c|c|c|c|c|c|}
\hline \multirow[b]{2}{*}{ Cultivar } & \multirow[b]{2}{*}{ Seed source ${ }^{v}$} & \multicolumn{3}{|c|}{ Measurements $(\mathrm{cm})^{\mathrm{z}}$} & \multicolumn{2}{|c|}{ Flowering $(\mathrm{d})^{\mathrm{y}}$} & \multicolumn{2}{|c|}{ Cultivar quality ${ }^{\mathrm{x}}$} & \multicolumn{2}{|c|}{ Pest symptomsw } & \multirow{2}{*}{$\begin{array}{c}\text { Overall } \\
\text { performance } \\
\text { rating }\end{array}$} \\
\hline & & $\begin{array}{c}\text { Plant } \\
\text { ht }\end{array}$ & $\begin{array}{l}\text { Plant } \\
\text { width }\end{array}$ & $\begin{array}{l}\text { Flower } \\
\text { diam }\end{array}$ & $\begin{array}{c}\text { First } \\
\text { flower }\end{array}$ & $\begin{array}{l}\text { Flowering } \\
\text { divergence }\end{array}$ & $\begin{array}{l}\text { Foliage } \\
\text { rating }\end{array}$ & $\begin{array}{l}\text { Flower } \\
\text { rating }\end{array}$ & $\begin{array}{l}\text { Foliage } \\
\text { rating }\end{array}$ & $\begin{array}{l}\text { Flower } \\
\text { rating }\end{array}$ & \\
\hline \multicolumn{12}{|c|}{ White with yellow class } \\
\hline Iona Frosty Lemon ${ }^{r}$ & Takii & 15 & 24 & 4.9 & $\begin{array}{c}72 \\
\text { Yellow clas }\end{array}$ & 9.7 & 4.7 & 3.7 & 6.3 & 4.7 & 4.8 \\
\hline Atlas Primrose & Bodger & 16 & 29 a & $5.6 \mathrm{a}$ & $68 \mathrm{~b}$ & 20.0 & 5.0 & $3.2 \mathrm{bc}$ & $6.5 \mathrm{~b}$ & $4.6 \mathrm{~b}$ & $4.8 \mathrm{bc}$ \\
\hline Atlas Yellow & Bodger & 17 & $28 \mathrm{a}$ & $4.9 \mathrm{~b}$ & $72 a b$ & 11.0 & 4.7 & $2.8 \mathrm{~cd}$ & $6.8 \mathrm{a}$ & $4.0 \mathrm{c}$ & $4.6 \mathrm{c}$ \\
\hline $\begin{array}{l}\text { Panola Golden Yellow } \\
\text { Character Clear }\end{array}$ & PanAmerican & $16^{\mathrm{NS}}$ & 26 a & $3.8 \mathrm{c}$ & $77 \mathrm{a}$ & $17.0^{\mathrm{NS}}$ & $5.2^{\mathrm{NS}}$ & $3.6 \mathrm{~b}$ & $6.8 \mathrm{a}$ & $4.6 \mathrm{c}$ & $5.0 \mathrm{~b}$ \\
\hline Primrose & Grimes & 19 & 29 a & $5.0 \mathrm{~b}$ & $72 \mathrm{ab}$ & 29.0 & 4.8 & $2.5 \mathrm{~d}$ & $6.5 \mathrm{~b}$ & $4.2 \mathrm{c}$ & $4.5 \mathrm{c}$ \\
\hline \multicolumn{12}{|c|}{ Yellow with blotch class } \\
\hline $\begin{array}{l}\text { Colossus Yellow With } \\
\text { Blotch } \\
\text { Delta Premium }\end{array}$ & Syngenta & 13 & 25 & $5.7 \mathrm{a}$ & 85 a & $20.0 \mathrm{ab}$ & 4.9 & $2.3 \mathrm{c}$ & $6.2 \mathrm{c}$ & $4.0 \mathrm{c}$ & $4.3 \mathrm{~b}$ \\
\hline $\begin{array}{l}\text { Yellow With Blotch } \\
\text { Fama Dark Eyed }\end{array}$ & Syngenta & 14 & 24 & $5.0 \mathrm{a}$ & $78 \mathrm{~b}$ & $5.7 \mathrm{~b}$ & 4.3 & $3.7 \mathrm{~b}$ & $6.8 \mathrm{a}$ & $4.9 \mathrm{a}$ & $4.9 \mathrm{a}$ \\
\hline $\begin{array}{l}\text { Yellow } \\
\text { Panola Yellow With }\end{array}$ & Benary & 14 & 23 & $5.4 \mathrm{a}$ & $83 \mathrm{ab}$ & $28.0 \mathrm{a}$ & 4.4 & $2.7 \mathrm{c}$ & $6.4 \mathrm{bc}$ & $4.4 \mathrm{~b}$ & $4.4 \mathrm{~b}$ \\
\hline \multicolumn{12}{|c|}{ Yellow with blotch and purple (blue-violet) cap class } \\
\hline $\begin{array}{l}\text { Garden Leader Character } \\
\text { Yellow \& Blue With Face }\end{array}$ & Grimes & 16 & 25 & 4.8 & 68 & 20.3 & 5.1 & 2.6 & 6.5 & 5.0 & 4.8 \\
\hline
\end{tabular}

${ }^{2} 1 \mathrm{~cm}=0.3937$ inch.

yhe number of days from sowing seed to the unfurling of the first flower in a plot. Divergence is the average number of days that lapse between the unfurling of the first flower and the last flower in a plot, or a measure of uniform flowering.

${ }^{x}$ Average of three foliage or flower quality ratings taken between 16 Jan. and 7 Apr. on a scale of 1 to 7 with $7=$ excellent.

wAverage of two arthropod and disease ratings for foliage and for flowers taken between 24 Jan. and 2 Mar. on a scale of 1 to 7 with $7=$ all foliage or flowers in a plot were free from arthropod feeding or plant disease symptoms.

"Seed sources: Benary = Ernst Benary of America, Sycamore, Ill.; Bodger Seeds, South El Monte, Calif.; Floranova = Floranova Services, Hutchins Road, Litchfield, Mich.; Goldsmith = Goldsmith Seeds, Gilroy, Calif.; Grimes = Grimes Seeds \& Plants, Concord, Ohio; PanAmerican = PanAmerican Seed Co., West Chicago, Ill.; Sakata = Sakata Seed America, Morgan Hill, Calif.; Syngenta = Syngenta Seeds, S\&G Flowers, Downers Grove, Ill.; Takii = American Takii, Salinas, Calif.

"Overall performance rating is the average of the foliage, flower, arthropod and disease ratings.

${ }^{t}$ Mean separation within classes by Duncan's multiple range test, $P<0.05$

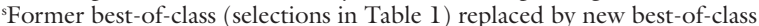

${ }^{r}$ Best-of-class chosen from the highest overall performance rating or by another rating, if overall performance values were equal.

${ }^{\mathrm{q}} \mathrm{NS}=$ Nonsignificant.

PNames were later changed by the seed company: 'Panache' cultivars used to create the 'Panola' series (see Table 1 for 'Baby Bingo' renamed 'Panola').

Purple (DARK), RED-VIOLET WiTh BLOTCH Class. 'Iona Purple With Blotch' was uncontested best-of-class in 2002 with an overall performance rating of 4.4. However, very poor to fair flower quality and poor flower pest symptom ratings lowered overall performance.

Purple (DARK), RED-Violet With BLOTCH (BLUE VIOLET RIM) CLASS. 'Giga Purple With Blotch' was uncontested best-of-class in 2003 with an overall performance rating of 4.8. 'Giga Purple With Blotch' had an unsatisfactory flower display all season. More plants died per plot than all other cultivars in this trial, resulting in the lower performance rating.

Purple (DARK), Red/White Class (PICOTEE PATTERN). 'Springtime Cassis' was uncontested best-of-class in 2002 with an overall performance rating of 5.0.

Purple with light Blotch Class. 'Baby Bingo Lavender Blue' was best-of-class in 2001 with an overall performance rating of 5.8. Other cultivars ranged from 4.7 for 'Purple Jester' to 5.4 for 'Purple Rain'. The class name was changed from "eye" to "blotch" after 2004.

Purple shades/tints with YELLOW/WHITE FACE AND BLOTCH. 'Majestic Giants II Marina Shades' was uncontested best-of-class in 2004 with an overall performance rating of 5.4.

Purple shades/tints class. 'Lavender Cool Shades' was best-ofclass in 2001 (class name changed from purple in 2002) with an overall performance rating of 5.0. Other cultivars ranged from 4.8 for 'Fama Lilac Shades' to 4.9 for Dynamite Lavender'

RED Class. 'Dynamite Scarlet' and 'Scala Scarlet' had an equal overall performance rating of 4.4 in 2001 . In this case, 'Dynamite Scarlet' was selected best-of-class in 2001 using the average of the foliage and flower ratings of 4.0 compared to 3.3 for 'Scala Scarlet'. Foliage and flower quality ratings were poor to fair all season; lack of flower color stability, showing yellow or orange, lowered ratings. Thrips damage to flowers was severe between 9 and 24 Mar., and flower disease ratings low on 10 Apr. These factors resulted in the lower overall performance for the class.

RED WITH BLOTCH/YELLOW CLASS. 'Dynamite Wine Flash' was established as uncontested best-of-class in 2004. It was evaluated in a special trial against 'Karma Red Blotch' that has a similar red with blotch. The overall performance rating for 'Dynamite Wine Flash' was 5.4 compared to 5.1 for 'Karma Red Blotch'.

RED WITH BLOTCH ClAss. 'Karma Red Blotch' was uncontested bestof-class in 2001 (class name changed from dark eye to blotch in 2002) with an overall performance rating of 4.7. Other cultivars ranged from 4.3 for 'Bingo Red With Blotch' and 'Dynamite Red With Blotch' to 4.6 for 'Baby Bingo Fire' (renamed 'Panola Fire'). In 2002, 'Karma Red Blotch' had a rating of 5.0 compared to ratings ranging from 4.1 for 'Bingo Red With Blotch' to 4.4 for 'Colossus Red With Blotch', in 2003, it had a rating of 5.3 compared to 4.7 for 'Giga Red With Blotch' and thus remained best of class.

Rose class. 'Karma Rose' was established as uncontested best-of-class 
Table 3. Plant and flowering characteristics and performance ratings for pansies grown in winter/spring 2002-03 in Bradenton, Fla., grouped within classes according to flower color. Seeds were sown on 10-17 Oct. 2002, and plugs transplanted to ground beds 11 Dec. 2002.

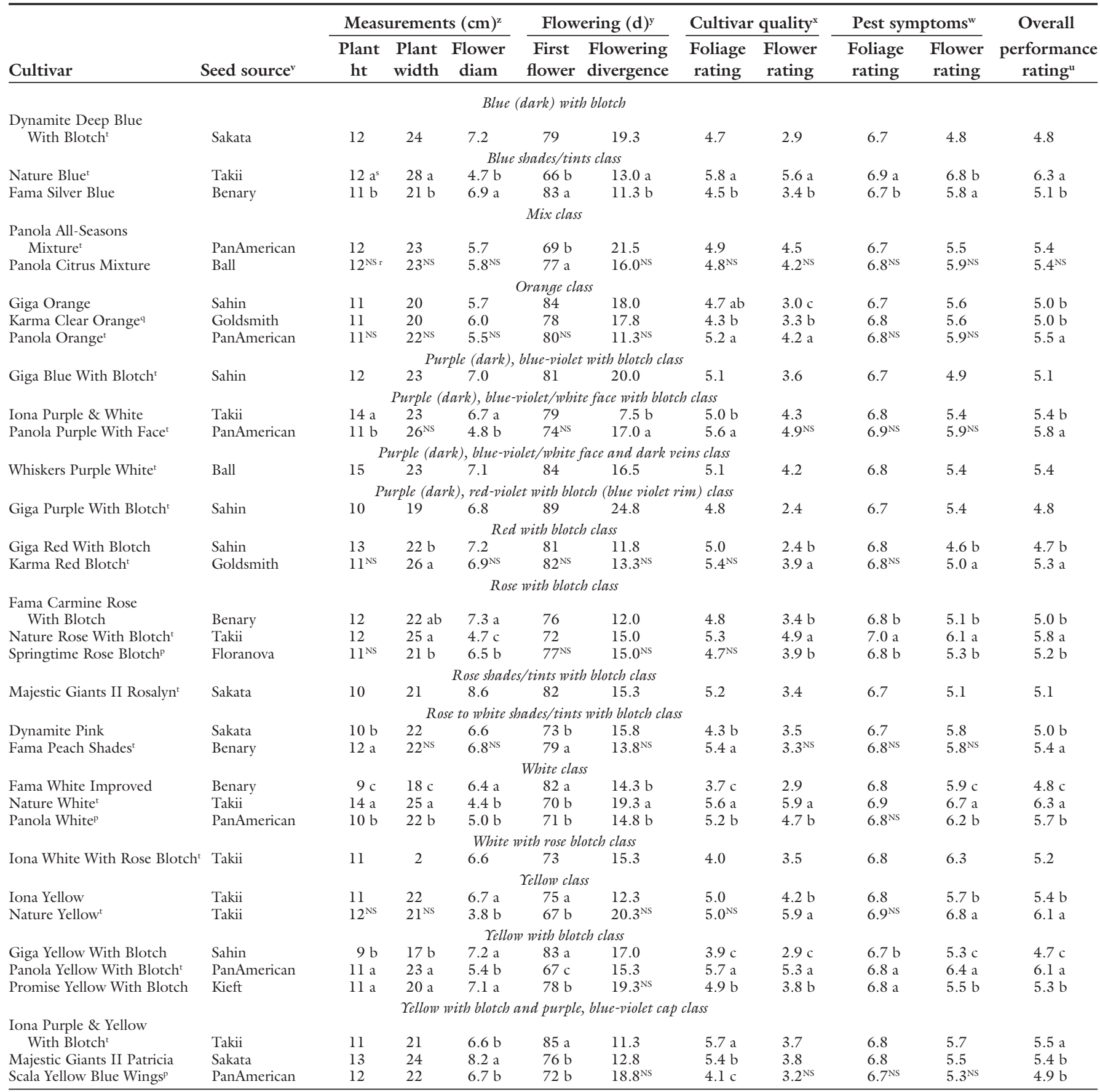

${ }^{2} 1 \mathrm{~cm}=0.3937$ inch.

y The number of days from sowing seed to the unfurling of the first flower in a plot. Divergence is the average number of days that lapse between the unfurling of the first flower and the last flower in a plot, or a measure of uniform flowering.

xAverage of three foliage or flower quality ratings taken between $15 \mathrm{Jan}$. and 15 Mar. on a scale of 1 to 7 with $7=$ excellent.

"Average of three arthropod and disease ratings taken between 17 Jan. and 16 Mar. on a scale of 1 to 7 with 7 = all foliage or flowers in a plot were free from arthropod feeding or plant disease symptoms.

"Seed Sources: Ball = Ball Seed Co., West Chicago, Ill.; Benary = Ernst Benary of America, Sycamore, Ill.; Floranova = Floranova Services, Hutchins Road, Litchfield, Mich.; Goldsmith = Goldsmith Seeds, Gilroy, Calif.; PanAmerican = PanAmerican Seed Co., West Chicago, Ill.; Sahin = K. Sahin (North America), Vista, Calif.; Sakata = Sakata Seed America, Morgan Hill, Calif.; Takii = American Takii, Salinas, Calif.

"Overall performance rating is the average of the foliage, flower, arthropod and disease ratings.

'Best-of-class was chosen from the highest overall performance rating or by another rating, if overall performance values were equal.

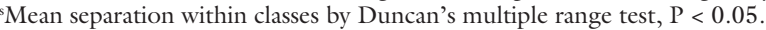

${ }^{\mathrm{r}} \mathrm{NS}=$ Nonsignificant.

"'Karma Clear Orange' became 'Karma Orange' after trial.

'pFormer best-of-class (selections in Tables 1 and 2) replaced by new best-of-class. 
Table 4. Statistical means for plant height, width, flower diameter, average combined cultivar quality ratings and pest ratings of pansies grown in winter/spring 2003-04 in Bradenton, Fla., grouped within classes according to flower color. Seeds were sown on 6-20 Oct. 2003 and plugs, transplanted to ground beds 17-24 Nov. 2003.

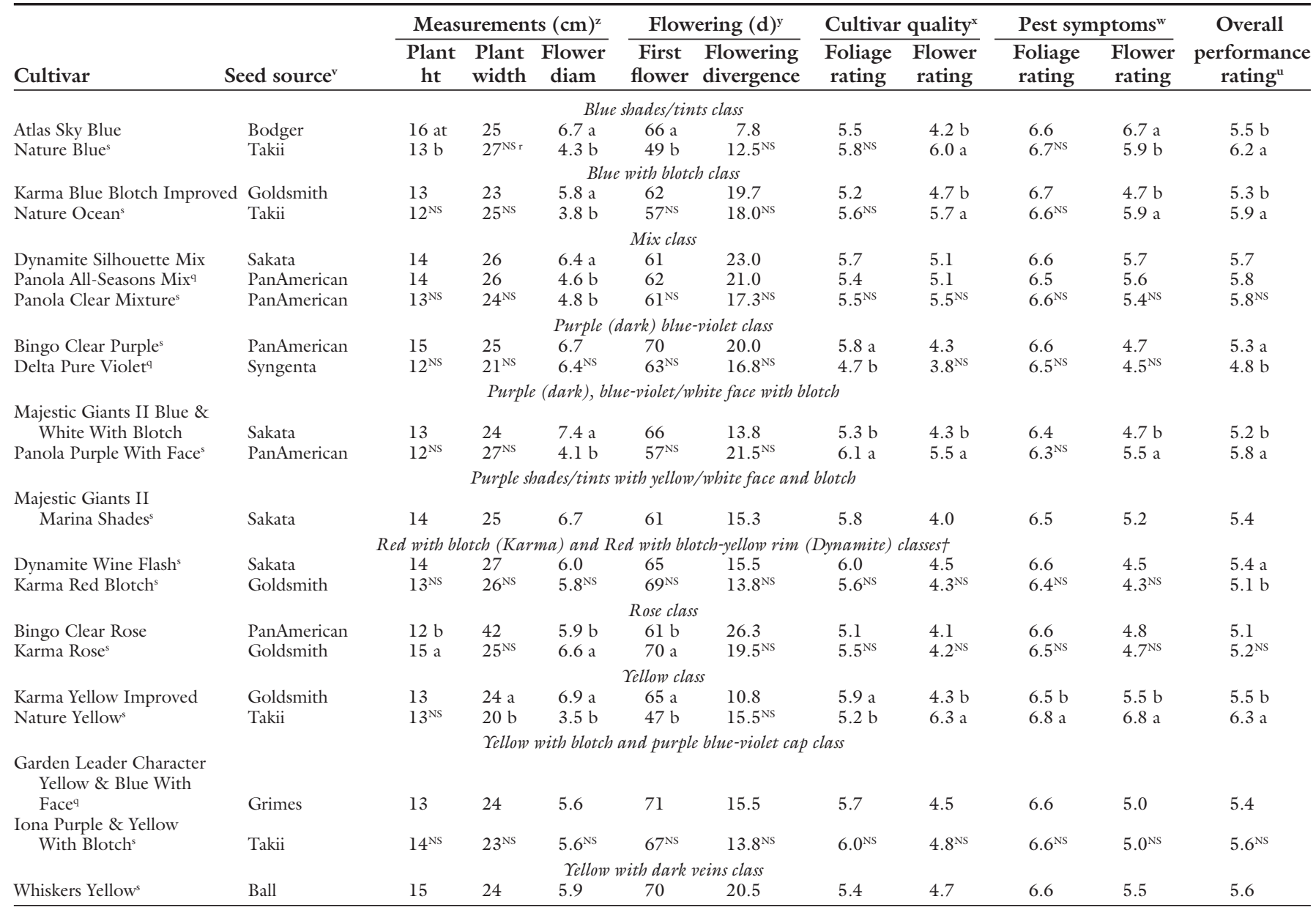

${ }^{\mathrm{z}} 1 \mathrm{~cm}=0.3937$ inch

The number of days from sowing seed to the unfurling of the first flower in a plot. Divergence is the average number of days that lapse between the unfurling of the first flower and the last flower in a plot, or a measure of uniform flowering.

xAverage of four foliage or flower quality ratings taken between 7 Jan. and 5 Mar. on a scale of 1 to 7 with $7=$ excellent.

wAverage of four arthropod and disease ratings for foliage and for flowers taken between 8 Jan. and 5 Mar. on a scale of 1 to 7 with $7=$ all foliage or flowers in a plot were free from arthropod feeding or plant disease symptoms.

"Seed Sources: Ball = Ball Seed Co., West Chicago, Ill.; Bodger Seeds, South El Monte, Calif.; Goldsmith = Goldsmith Seeds, Gilroy, Calif.; Grimes = Grimes Seeds \& Plants, Concord, Ohio; PanAmerican = PanAmerican Seed Co., West Chicago, Ill.; Sakata = Sakata Seed America, Morgan Hill, Calif.; Syngenta = Syngenta Seeds, S\&G Flowers, Downers Grove, Ill.; Takii = American Takii, Salinas, Calif.

"Overall performance rating is the average of the foliage, flower, arthropod and disease ratings.

'Mean separation within classes by Duncan's multiple range test, $P<0.05$.

${ }^{s}$ Best-of-class marked with an asterisk $\left(^{*}\right)$; chosen from the highest overall performance rating or by another rating, if overall performance values were equal.

${ }^{\mathrm{r} S}=$ Nonsignificant

${ }^{q}$ Former best-of-class (selections in Tables 1, 2, and 3) replaced by new best-of-class.

in 2001 with an overall performance rating of 4.6. In 2002, 'Karma Rose' had a rating of 4.6 compared to ratings ranging from 4.2 for 'Atlas Rose' to 4.4 for 'Delta Pure Rose'. In 2004, 'Karma Rose' had a rating of 5.2 compared to a rating 5.1 for 'Bingo Clear Rose', and thus remained best of class. Rose has been a weaker class, affected by poor ratings for all aspects of performance.

Rose WITH BLOTCH ClASS. 'Nature Rose With Blotch' was established as best-of-class in 2003 with an overall performance rating of 5.8. Other cultivars ranged from 4.9 for 'Springtime
Rose Blotch', the former best-of-class in the 2002 trial, to 5.0 for 'Fama Carmine Rose With Blotch'. Unlike the rose class, the rose with blotch class performed well with 'Nature Rose With Blotch' genetics.

ROSE SHADES/TINTS WITH BLOTCH CLAss. 'Majestic Giants II Rosalyn' was uncontested best-of-class in 2003 with an overall performance rating of 5.1. Poor flower quality ratings before March and a very poor flower disease symptom rating on 16 Feb. lowered the overall performance rating.

ROSE TO WHITE SHADES/TINTS with вLотCH Class. 'Fama Peach
Shades' was best-of-class in 2003 with an overall performance rating of 5.4 , compared to 5.0 for 'Dynamite Pink'.

White Class. 'Nature White' was established as best-of-class in 2003 with an overall performance rating of 6.3. Other cultivars ranged from 4.8 for 'Fama White Improved' to 5.7 for 'Panola White', the former best-of-class from the 2002 trial.

White WITH BLOTCH CLASS. The class name was changed from dark eye to blotch after 2001. 'Iona White with Blotch' and 'Karma White Blotch' had an equal overall performance rating of 
5.0 in 2002. 'Iona White with Blotch' was selected best-of-class based on the significantly different overall flower pest rating of 5.6 compared to 5.5 for 'Karma White Blotch'. Other cultivars ranged from 4.4 for 'Colossus White With Blotch' to 4.6 for 'Scala White With Blotch', the former best-of-class from the 2001 trial.

WHITE FACE WITH ROSE CAP AND BLOTCH Class. 'Bingo Rose \& White' was uncontested best-of-class in 2002 with an overall performance rating of 4.9. Poor flower pest symptom ratings through $27 \mathrm{Feb}$. caused the overall performance rating to fall to a fair level.

WHITE WITH ROSE BLOTCH CLASS. 'Iona White With Rose Blotch' was uncontested best-of-class in 2003 with an overall performance rating of 5.2.

White With Yellow Class. 'Iona Frosty Lemon' was uncontested best-of-class in 2002 with an overall performance rating of 4.8 . Flower quality ratings were poor from 16 Jan. to 27 Feb., but were good on 7 Apr. In contrast, foliage quality ratings were good in January and February, but very poor on 7 Apr. Pest ratings were low for flower disease symptoms. These variable ratings contributed to the lower performance rating.

Yellow Class. 'Nature Yellow' was best-of-class in 2002 with an overall performance rating of 5.7. Other cultivars ranged from 4.6 for 'Atlas Yellow' to 5.0 for 'Panola Golden Yellow' (formally 'Baby Bingo Yellow;' best of class in the 2001 trial). In 2003, 'Nature Yellow' had a rating of 6.1 compared to 5.4 for 'Iona Yellow'. In 2004 , it had a rating of 6.3 compared to 5.5 for 'Karma Yellow Improved', and thus remained best of class.

YELLOW WITH BLOTCH CLASS. 'Panola Yellow With Blotch' (formally Panache Yellow With Blotch) was bestof-class in 2002 with an overall performance rating of 5.1, compared to 4.4 for 'Fama Dark Eyed Yellow', the former best-of-class (when class divided in 2001). Other cultivars ranged from 4.3 for 'Colossus Yellow With Blotch' to 4.9 for 'Delta Premium Yellow With Blotch'. In 2003, 'Panola Yellow With Blotch' had a rating of 6.1 compared to ratings ranging from 4.7 for 'Giga Yellow With Blotch' to 5.3 for 'Promise Yellow With Blotch'.

YELLOW WITH BLOTCH AND RED CAP CLASs. Yellow with blotch class was divided in 2001, moving 'Bingo Red \& Yellow' into the new class to become uncontested best-of-class with an overall performance rating of 5.1.

YELLOW WITH BLOTCH AND PURPLE, BLUE-VIOLET CAP Class. 'Iona Purple \& Yellow With Blotch' was best-of-class in 2003 with an overall performance rating of 5.5. Other cultivars ranged from 4.9 for 'Scala Yellow Blue Wings' (former best-of-class removed from the yellow with blotch class in 2001) to 5.4 for 'Majestic Giants II Patricia'. In 2004, 'Iona Purple \& Yellow With Blotch' had a rating of 5.6 compared to 5.4 for 'Garden Leader Character Yellow \& Blue With Face' (former uncontested best-of-class in 2002), and thus remained best of class.

YELLOW WITH DARK VEINS CLASS. 'Whiskers Yellow' was uncontested best-of-class in 2004 with an overall performance rating of 5.6.

\section{Selecting outstanding cultivars}

Those cultivars with the highest overall rating in their class (best-ofclass) will be considered as standards for comparison with new releases in future trials, regardless of their relative performance, in order to eliminate the need for re-evaluation of so many cultivars. The ideal situation would be to have the best-of-class with an outstanding performance rating. Other cultivars in the same class may be statistically similar in overall performance, but have a lower rating value. Outstanding current bestof-class were: 'Accord/Banner Black Beauty', 'Baby Bingo Lavender Blue', 'Bingo Red \& Yellow', 'Iona Purple \& Yellow With Blotch', 'Nature Beacon', 'Nature Blue', 'Nature Ocean', 'Nature Pink Shades', 'Nature White', 'Nature Yellow', 'Panola Clear Mixture', 'Panola Purple With Face', 'Panola Yellow With Blotch', and 'Whiskers Yellow'. Outstanding former best-of-class were 'Atlas Sky Blue', 'Panola All Seasons Mixture', 'Panola Beaconsfield', 'Panola White', and 'Scala Clear White'. 'Dynamite Silhouette Mix' was also outstanding, but not best-of-class.

While our irrigation/soil type/ fertilization practices may not represent cultural practices in other landscape situations, our choice of these growing conditions was to provide uniform and sufficient nutrients and moisture to allow for outstanding growth and flowering of pansies. Soil amendments and irrigation are typically used in bedding plant trials (Pemberton and Roberson, 2001), and indeed most gardeners and landscapers modify their soil and provide irrigation/fertilizer to maximize plant growth and flowering. Thus, performance evaluations for bedding plants are more likely influenced by climatic conditions than by culture. We believe these performance evaluations would provide useful information for the bedding plant industry in the southeastern U.S. or other parts of the world with similar climatic conditions.

\section{Literature cited}

Alfieri, Jr., S.A., K.R. Langdon, J.W. Kimbrough, N.E. El-Gholl, and C. Wehlburg. 1994. Diseases and disorders of plants in Florida. Fla. Dept. Agr. Consumer Services Bul. 14.

American Horticultural Society. 1999. Heat zone map. 14 Nov. 2004. <http://www.ahs. org/publications/heat_zone_map.htm>.

Bailey, L.H. 1947. The standard cyclopedia of horticulture. Macmillan, New York.

Farr, D.F., G.F. Bills, G.P. Chamuris, and A.Y. Rossman. 1989. Fungi on plants and plant products in the United States. Amer. Phytopathol. Soc., St. Paul, Minn.

Florida Automated Weather Network. 2004 FAWN: Report generator. 14 Nov. 2004. <http://fawn.ifas.ufl.edu/scripts/reportrequest.asp $>$.

Howe, T.K. and W.E. Waters. 1989. Pansy cultivar evaluation in the landscape. Proc. Fla. State Hort. Soc. 102:97-101.

Kessler, J.R. 1998. Pansy production and marketing. Auburn Univ., ANR-596. 14 Nov. 2004. <http://www.aces.edu/pubs/docs/A/ ANR-0596/>.

Pemberton, H.B. and W.E. Roberson. 2001. The east Texas bedding plant pack and garden performance trials. HortTechnology 11:392-396.

Texas A\&M Univ. 1997. PLANTanswers information about flowers: Pansypansy. 14 Nov. 2004. <http://aggie-horticulture.tamu.edu/ plantanswers/flowers/pansies.html>.

U.S. Dept. of Agriculture, National Agricultural Statistics Service. 1998. 1998 Census of horticultural specialties: Annual bedding/garden plants sold for the United States. 14 Nov. 2004. <http://www.nass.usda.gov/census/census97/horticulture/table04-07.pdf>.

U.S. Dept. of Agriculture, Agricultural Research Service and Germplasm Resources Information Network, National Genetic Resources Program. 2004a. Data from GRIN taxonomy: Taxon: Viola xwittrockiana Gams. 14 Nov. 2004. <http:// www.ars-grin.gov/cgi-bin/npgs/html/taxon. pl:31223l>

U.S. Dept. of Agriculture, National Agricultural Statistics Service. 2004b. Floricultural crops 2003 summary. U.S. Dept. Agr., Washington, D.C.

U.S. National Arboretum. 1990. USDA Plant hardiness zone map. 14 Nov. 2004. <http:// www.usna.usda.gov/Hardzone/ushzmap. html>. 